\title{
Petrochemistry of Lan Sang metamorphic suites
}

\author{
Somporn Wonglak, Chakkaphan Sutthirat, Thitiphan Assawincharoenkij* \\ Department of Geology, Faculty of Science, Chulalongkorn University, Bangkok 10330 Thailand
}

*Corresponding author, e-mail: thitiphan.a@chula.ac.th

Received 6 Jun 2020

Accepted 2 Aug 2020

\begin{abstract}
Western metamorphic belt in Thailand elongated in North-South direction has been grouped into the Chiang Mai-Lincang belt. As part of this metamorphic belt, the Lan Sang National Park located in the west of Tak Province is an affected area from northwest-southeast striking Mae Ping fault. Along the fault zone, rock formations have been strongly deformed, yielding steep foliation and lineation. Based on petrographic study, these rocks are mainly characterized by gneisses showing very fine- to coarse-grained textures which consist of quartz, plagioclase, K-feldspar, biotite, pyroxene, and chlorite. Calc-silicate and impure marble are partly interlayered in these gneisses; they are composed of calcite, quartz, feldspar, pyroxene, and garnet. Moreover, granitic gneiss, which cuts into the host gneisses and calc-silicate, appears to have a similar composition of gneiss. Based on geothermobarometry, these rocks should have undertaken high-grade metamorphism of lower amphibolite facies with P-T (pressure-temperature) ranges of $570-590^{\circ} \mathrm{C}$ and 5.8-8.1 Kbar for gneiss. These rocks appear to have several evolution stages. Sedimentary protoliths of gneisses and calc-silicate may have situated in the area prior to regional metamorphism. Subsequently, dikes and veins crosscut into these gneissic and calc-silicate rocks before later metamorphism appears to have continued and reached the ductile-brittle stage.
\end{abstract}

KEYWORDS: gneiss, calc-silicate, geothermobarometry, protolith, rock metamorphism, petrographical characteristics

\section{INTRODUCTION}

Thailand consists of two main tectonic microcontinents, Shan-Thai to the west and Indochina to the east. Bunopas and Vella [1] reported that metamorphic rocks have widely exposed in all regions of the country. However, Northwestern Thailand is an important area in which many researchers have studied characteristics of metamorphic core complex [2-5] and volcanic activity [6]. Mountain ranges in this area extend stretchy towards the Mae Ping fault, which gradually changes the orientation along the fault directly to the NW-SE direction. They have been recognized as a sinistral strike-slip fault $[7,8]$. In Shan-Thai terrane, its basement is occupied by Precambrian high-grade metamorphic and Middle or Upper Paleozoic rocks characterized by various grades of metamorphism overprinting sedimentary sequences. They gradually change orientation in the north towards the northwestsoutheast direction [3, 4, 9]. Most rocks usually show steep foliations and stretched lineations [2], which are an indicator of the sinistral shear movement that was found around the Lan Sang National Park in Tak province (Fig. 1).

Furthermore, Palin [7] and Österle [10] mentioned that the Mae Ping strike-slip motion expo- sures of high-grade orthogneiss in this area contain strong mylonitic textures and ductile-brittle shear rocks. Two crystallization stages inferred from geochronological analysis of monazite in orthogneiss, with core regions $\mathrm{Th}-\mathrm{Pb}$ ages between about 123 and $114 \mathrm{Ma}$. Rim region ages range

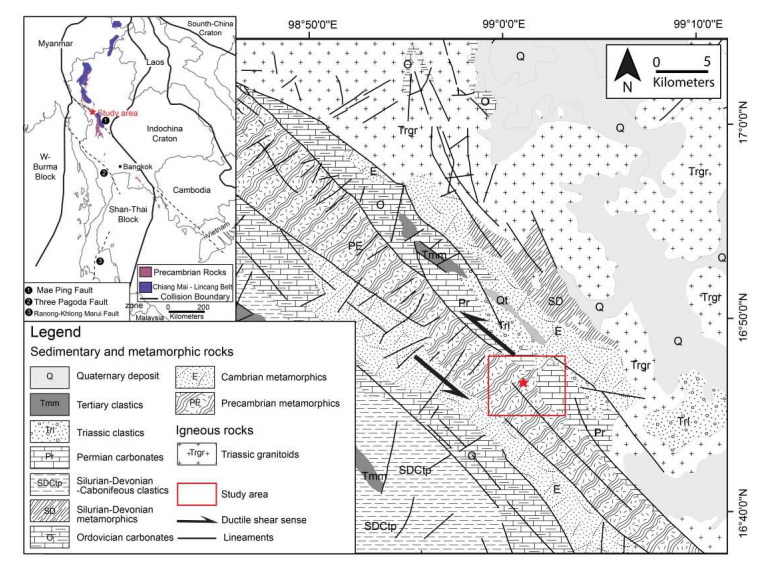

Fig. 1 Index map of Thailand and adjacency shows the distribution of Precambrian rock along North-South elongation (revised from [5]). Geologic map of Tak province (revised from $[8,9]$ ) reveals the location of the study area (in the red box). 
between about 45-37 Ma ( $\mathrm{Ma}=$ million years ago), which can indicate metamorphism occurring during the Eocene.

Rock formations surrounding the study area are composed of metamorphic rocks, sedimentary rocks, and slightly covered by unconsolidated sediments (Fig. 1), based on Department of Mineral Resources [9].

The study area, the Lan Sang National Park, located in the west of Tak province is a part of the affected area from northwest-southeast striking fault. However, the effected domain of the Mae Ping strike-slip fault zone is still unclearly known, particularly metamorphic evolution as well as P-T data [5]. Therefore, this study is focused on petrographical, mineralogical, and geochemical characteristics of these metamorphic rocks. Consequently, metamorphism and P-T condition can be carried out for further discussion on tectonic evolution in the region.

\section{MATERIALS AND METHODS}

Fifty-four rock samples were collected from the study area, Lan Sang National Park, during the field investigation. More than 20 samples of metamorphic rocks were then selected and prepared as thin sections and polished-thin sections for petrographic description and mineral chemical analysis, respectively. Moreover, rock powders and solutions were also prepared for whole-rock geochemical analyses.

Electron Probe Micro-Analyzer (EPMA: Model JEOL JXA-8100) was engaged to analyze crucial mineral assemblages at Department of Geology, Faculty of Science, Chulalongkorn University. Mineral and oxide standards were used for calibration using a focused beam $(<1 \mu \mathrm{m}$ in diameter) under the operating condition of $15 \mathrm{kV}$ acceleration voltage and about $25 \mathrm{nA}$ beam current. The same conditions were applied for all analyses before automatic $\mathrm{ZAF}$ (Z (stands for atomic number) absorption and fluorescence) correction.

Major and minor compositions of rock samples were obtained using an X-ray Fluorescence (XRF) Spectrometer (a Bruker AXS S4 PIONEER) at Department of Geology, Faculty of Science, Chulalongkorn University. These quantitative analyses were operated at $220 / 380 \mathrm{~V}, 50 \mathrm{~Hz}, 8 \mathrm{kVA}$. Rock standards provided by USGS (the United States Geological Survey) and Geological Society of Japan were selected for calibration before reporting in wt.\% oxides. Moreover, loss on ignition (LOI) was measured by weighting rock powders compared before and after $3 \mathrm{~h}$ ignition at $1000^{\circ} \mathrm{C}$ in RHF 14-3
$220 \mathrm{~V}$ electric furnace.

In addition, trace elements and rare earth elements (REE) were analyzed by Inductively Coupled Plasma-Mass Spectrometer (ICP-MS) based at the Mineral and Geological Services, SGS (Thailand) Limited. These samples were digested totally to the solution using sodium peroxide, leach with water, and add nitric acid. Detection limits were estimated, ranging from $0.05 \mathrm{ppm}$ to $1 \%$.

\section{RESULTS}

\section{Petrography}

The Lan Sang metamorphic suites show distributions of the main rock units, including gneissic rocks, calc-silicate rocks, and granitic gneiss. These rocks locally show mylonitic texture and ductile shear stretch of mineral. Detailed descriptions of each group are reported below.

Gneissic rocks can be characterized into three groups on the basis of mineral grain sizes, including very fine-grained $(0.1-1 \mathrm{~mm})$, fine-grained $(0.05-1 \mathrm{~cm})$, and coarse-grained $(0.3-2.5 \mathrm{~cm})$ gneissic rocks that are associated with pegmatite vein, leucocratic vein, and dike. Fine-grained gneissic rock layers show foliated and interbanded coarse-grained crystals, porphyroblastic to augen gneissic texture of quartz, plagioclase, and Kfeldspar. Stretched porphyroblasts are evidence of the ductile shear stage, including boudinage, rotating of clast, and $\sigma$-type of leucocratic vein. Moreover, some areas show brittle stage, including minor faults, cracks, and joints overprinting the ductile shear texture. Mineral compositions of these rocks are mainly composed of $35-40 \%$ quartz, 25-30\% plagioclase, 20-35\% K-feldspar, $12-15 \%$ biotite, and $5-8 \%$ pyroxene in some samples with minor contents of chlorite, monazite, apatite, zircon and opaque mineral. In general, petrographic features of these rocks are recognized as granoblastic groundmass surrounding porphyroblasts of plagioclase and K-feldspar within the white band (Fig. 2a-b) whereas lepidoblastic biotites are usually found in dark bands. The other textures are augen mylonitic texture (Fig. 2c) and poikilitic texture. Moreover, chlorites are mostly anhedral crystals formed around edges of biotite, which seem to be an indicator of retrograde process.

Calc-silicate rocks and impure marble are found interbanded with gneissic rocks. Their bands are mostly $<1 \mathrm{~m}$ thick. Calc-silicate rocks contain several layers (i.e., green, purple, brown, and white colors), which show stretched ductile clasts of leu- 

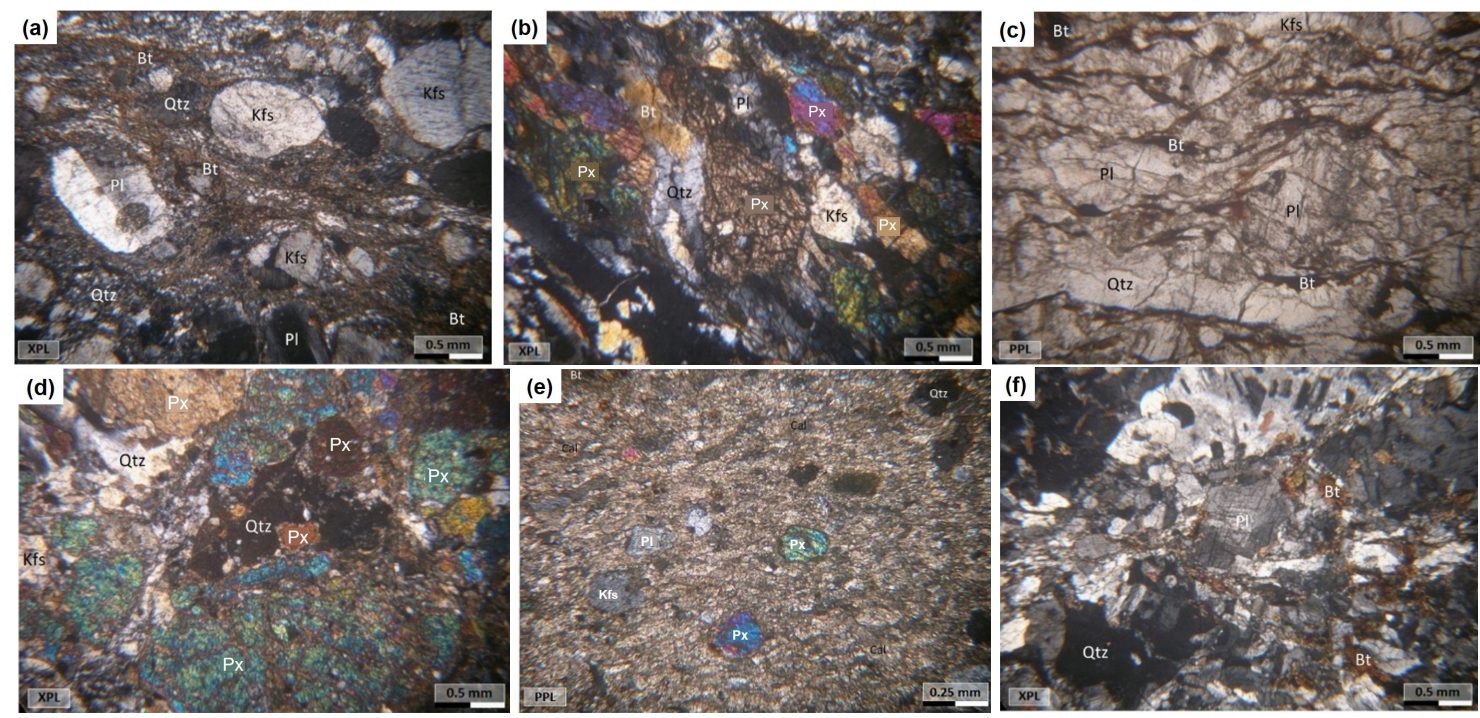

Fig. 2 Petrographic features of rocks: (a) various porphyroblasts surrounded by layered biotite matrix, (b) revealing subhedral to anhedral pyroxene and other porphyroblasts, (c) revealing augen mylonitic texture, (d) identified as pyroxene, biotite, calcite, plagioclase and quartz, (e) indicating porphyroblasts of pyroxene and feldspar embedded within very fine-grained calcite matrix, (f) showing granoblasts of quartz and plagioclase with poikilitic texture and triple junction and lepidoblastic biotite. Mineral symbols: Biotite (Bt), Pyroxene (Px), K-feldspar (Kfs), calcite (Cal), plagioclase (Pl) and quartz (Qtz).

cocratic vein crosscut into these rocks prior to shearlateral stretching. Calc-silicate rocks partly show alternate mylonitization of green, brown and white bands, which are composed of about 30\% quartz, $38 \%$ feldspar, $18 \%$ calcite, $10 \%$ pyroxene, $2 \%$ garnet, and chlorite. Additional dark grey bands consist of fine-grained calcite matrix with minor clasts of feldspar, quartz, and pyroxene (Fig. 2d). They also show sutured saccharoidal texture of recrystallized calcite. Porphyrogranoblastic textures with various grain sizes are presented in this rock type. Moreover, poikilitic texture and blastomylonitic texture are sometimes observed.

Pale to dark grey impure marble contains a majority of fine- to medium-grained calcitematrix (over 80-90\%) with minor clasts of quartz, feldspar, garnet, and pyroxene of which some reaction rims are often observed (Fig. 2e).

Granitic gneiss subsequently intruded into coarse-grained gneiss and calc-silicate rocks. These intrusions show foliation typically parallel to those observed in the host. Rock samples are characterized by medium-grained texture with average grain sizes ranging from 0.05 to $1 \mathrm{~cm}$. These rocks contain $40-45 \%$ quartz, $35-40 \%$ feldspar, $10-15 \%$ biotite, and a small amount of chlorite with rare zircon, monazite, and opaque minerals (Fig. 2f).
Granoblastic quartz and feldspar with lepidoblastic biotite (Fig. 2f) usually form anhedral crystals. Porphyroblasts with poikilitic texture and triple junction are presented in this rock type.

\section{Mineral chemistry}

Representative EPMA analyses of main minerals, e.g., pyroxene, feldspar, biotite, and chlorite are reported in Supplementary Tables S1-S5, and their details are described below.

Pyroxenes are mostly found in calc-silicate band, impure marble and some fine-grained gneiss samples. The compositions of pyroxene are present in Supplementary Table S1. Pyroxenes in gneiss consist of the followings in wt.\%: $54.5-57.3 \mathrm{SiO}_{2}$, 1.4-4.4 $\mathrm{Al}_{2} \mathrm{O}_{3}, 6.4-7.3 \mathrm{FeO}_{\text {Total }}$, 18.9-19.5 MgO, 12.9-13.2 CaO, and other negligible compositions. In calc-silicate rocks, pyroxenes are composed of the followings in wt.\%: 55.1-56.7 $\mathrm{SiO}_{2}, 2.0-2.4 \mathrm{Al}_{2} \mathrm{O}_{3}$, 10.3-14.3 $\mathrm{FeO}_{\text {Total }}, 14.3-17.1 \mathrm{MgO}, 12.6-13.5 \mathrm{CaO}$, and others. Moreover, pyroxenes in impure marble consist of the followings in wt.\%: $54.9-57.0 \mathrm{SiO}_{2}$, 1.8-3.6 $\mathrm{Al}_{2} \mathrm{O}_{3}, 5.0-9.5 \mathrm{FeO}_{\text {Total }}, 17.6-20.6 \mathrm{MgO}$, 13.1-13.6 $\mathrm{CaO}$, and other negligible compositions. All the analyses show almost consistent compositions of Mg-rich augite with high $\mathrm{Mg} / \mathrm{Fe}$ ratio. Although clinopyroxenes in fine-grained gneiss and impure marble yielded $X_{\mathrm{Mg}}=0.83-0.84$ and $X_{\mathrm{Mg}}=$ 
$0.77-0.88$ are slightly higher than those in calcsilicate rock $\left(X_{\mathrm{Mg}}=0.64-0.74\right)$.

Plagioclase and K-feldspar are the main assemblages of most rock types. Mineral chemical compositions of plagioclases found in this study are shown in Supplementary Table S2. Plagioclases in all rock samples are characterized by andesine to labradorite compositions ranging between An33-57, Ab41-67, and Or $\leqslant 2$. Although K-feldspar can be observed in all rock types, most of them are highly weathered. Only a few analyses of K-feldspar are reliable (Supplementary Table S3). They are characterized by orthoclase composition in all rock types, which range between An $\leqslant 2.5$, Ab4-15, and Or83-96.

Biotite grains are mostly found in gneiss and granitic gneiss. The selective analytical data are collected in Supplementary Table S4. In gneiss, biotites are mainly composed of the followings in wt.\%: 32.2-41.0 $\mathrm{SiO}_{2}, 1.1-3.5 \mathrm{TiO}_{2}, 16.6-19.5 \mathrm{Al}_{2} \mathrm{O}_{3}$, 21.1-27.3 $\mathrm{FeO}_{\text {Total }}$, 7.3-9.4 MgO, and 3.1-9.7 $\mathrm{K}_{2} \mathrm{O}$. Likewise, biotites in granitic gneiss consist mainly of 37.3-37.9 $\mathrm{SiO}_{2}, 2.9-4.0 \mathrm{TiO}_{2}, 15.9-16.0 \mathrm{Al}_{2} \mathrm{O}_{3}$, 20.9-22.1 $\mathrm{FeO}_{\text {Total }}, 8.1-8.8 \mathrm{MgO}$, and 9.6-9.6 $\mathrm{K}_{2} \mathrm{O}$.

Chlorites are mostly found in coarse-grained gneiss, very fine-grained gneiss, and granitic gneiss. They occur as secondary mineral altered from biotite, which indicates a retrograde reaction to lower temperature equilibrium. The analytical data are shown in Supplementary Table S5. In coarsegrained and very fine-grained gneisses, chlorites are composed of the followings in wt.\%: 25.9-28.4 $\mathrm{SiO}_{2}, 20.1-21.3 \mathrm{Al}_{2} \mathrm{O}_{3}, 27.1-31.2 \mathrm{FeO}_{\text {Total }}$, and 9.9-13.8 MgO. Chlorites in granitic gneiss are composed of the followings in wt.\%: 27.6-36.7 $\mathrm{SiO}_{2}$, 16.6-8.2 $\mathrm{Al}_{2} \mathrm{O}_{3}, 18.4-25.7 \mathrm{FeO}_{\text {Total }}, 8.9-11.4 \mathrm{MgO}$, $0.1-0.6 \mathrm{CaO}$, and $1.7-5.9 \mathrm{~K}_{2} \mathrm{O}$.

\section{Whole-rock geochemistry}

\section{Major and minor oxides}

Major and minor compositions of all rock types are reported in wt.\% oxides and summarized in Table 1. Harker variation diagrams were applied for the correlation of major and minor oxides (Fig. 3). In general, calc-silicate rocks have compositional ranges, e.g., $50-63$ wt. $\% \mathrm{SiO}_{2}, 10-20 \mathrm{wt} . \% \mathrm{CaO}$ and 8-10 wt. $\% \mathrm{Al}_{2} \mathrm{O}_{3}$, falling between gneiss samples and impure marbles of which the last group contains much higher $\mathrm{CaO}$ contents (40-55 wt.\%) and lower $\mathrm{SiO}_{2}$ content (27-36 wt.\%) (Table 1, Fig. 3).

\section{Trace elements}

Trace elements obtained from gneiss and granitic gneiss samples are reported in Supplementary Table S6. Primitive mantle-normalized spider diagram [11] is engaged for these analyses prior to comparison with the patterns of the average upper crust composition [12]. Zigzag patterns are commonly present in all gneiss samples, which are similar to the pattern of the average upper crust (Fig. 4a). Chondrite-normalized rare earth element patterns [11] of gneiss and granitic gneiss show compatible trend decreasing from La to Lu (Fig. 4b). These patterns are agreeable to the pattern of the average upper crust [12]. It should be a decreasing pattern from LREE to HREE (light to heavy REE) with a negative Eu anomaly.

\section{P-T estimation}

Pseudosection and geothermometer were applied for P-T estimation in this study. Whole-rock geochemical analyses were used to calculate pseudosection using PerPlex software [13-15]. Moreover, geothermometry was carried out using Petrological Elementary Tools (PET) for Mathematica calculation [16]. Consequently, coarse-grained gneiss (LS-23A) were selected for this P-T estimation. The proper pseudosection shows a group of mineral assemblages (Fig. 5a) with the most representative field of Chl-Pl-Phl-Ann-Kfs-Qtz- $\mathrm{H}_{2} \mathrm{O}$, which is stable in a wide P-T range. Geothermometry, based on biotite-chlorite (GT4, after [16]), is used to generate the lower isotherm of the equilibrium present in such pseudosection. Consequently, a range of P-T condition of coarse-grained gneiss falls within $570-590^{\circ} \mathrm{C}$ and 5.8-8.1 Kbar, which are compatible with the lower amphibolite facies.

\section{DISCUSSION}

\section{Protolith}

As a result, most gneiss and granitic gneiss samples are mainly plotted within the field of quartzofeldspathic protolith (Fig. 5b), which is potentially composed of greywacke sandstone and siltstone, based on ACF diagram [17]. Calc-silicate rocks fall closely to the calcareous rocks (Fig. 5b), whereas compositions of impure marble are plotted towards the Ca-enrichment apex. Based on $\mathrm{FeO}+\mathrm{MgO}$ versus $\mathrm{K}_{2} \mathrm{O} /\left(\mathrm{K}_{2} \mathrm{O}+\mathrm{Na}_{2} \mathrm{O}\right)$ diagram $[18,19]$, most samples have initial composition related to sedimentary rocks (e.g., arkose and shale) (Fig. 5c).

Chondrite-normalized REE patterns [11] (Fig. 4b) of all gneiss varieties are comparable to 


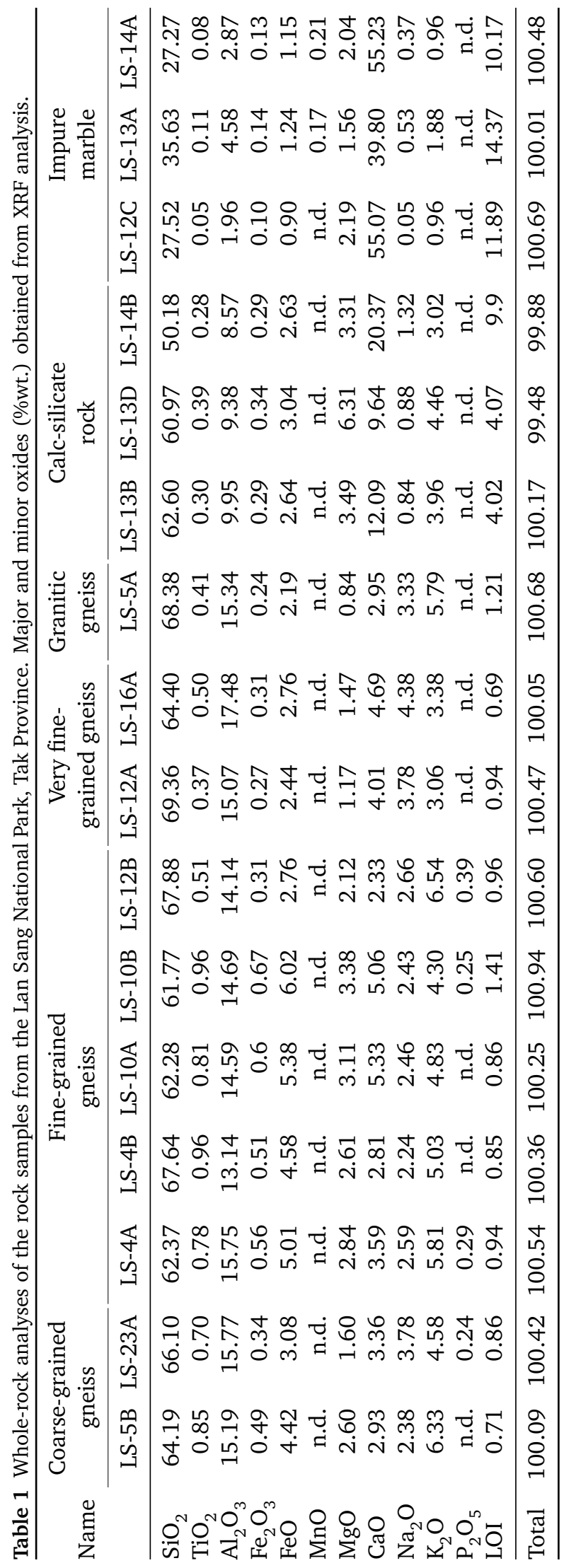



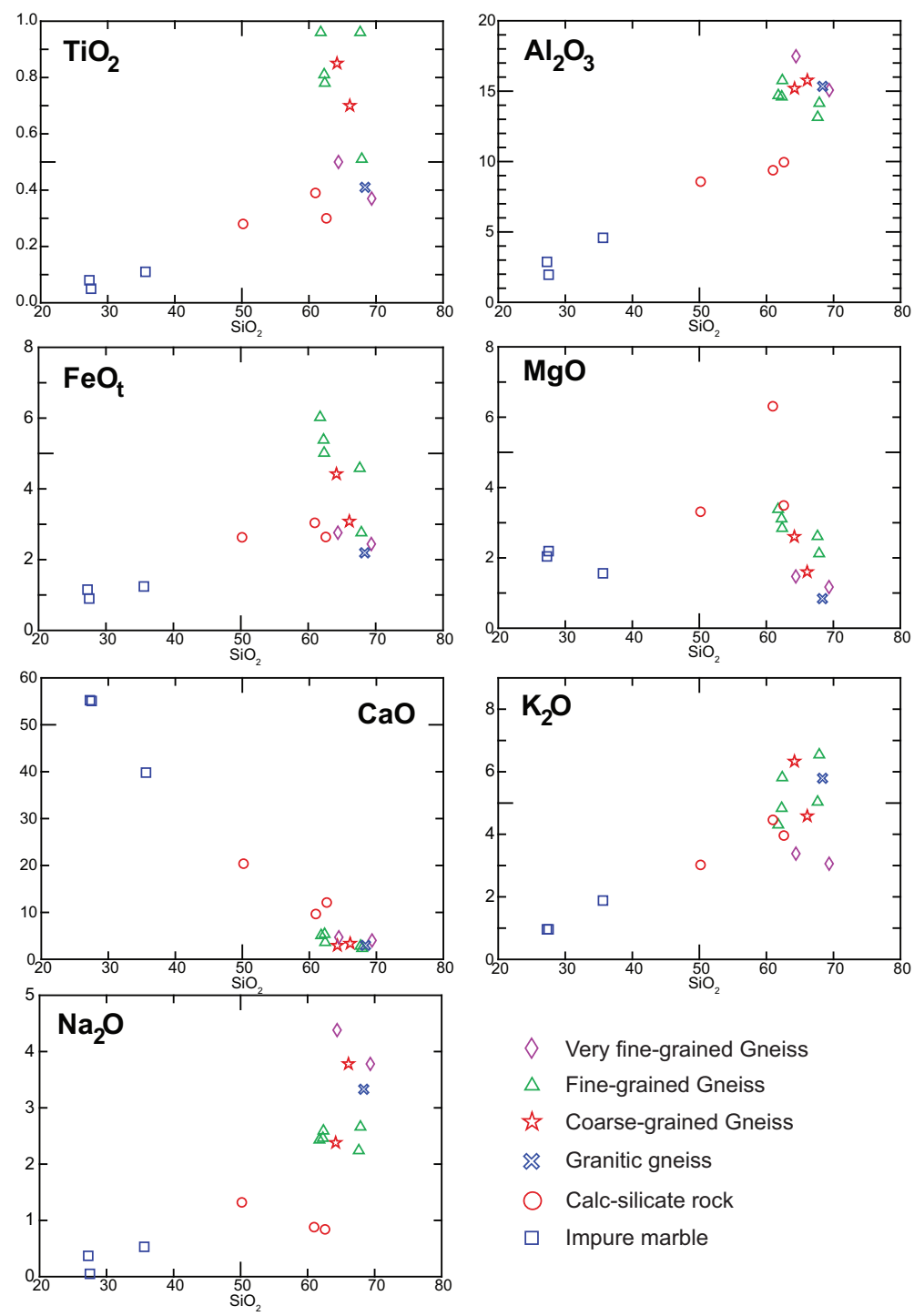

$\diamond \quad$ Very fine-grained Gneiss

$\triangle$ Fine-grained Gneiss

is Coarse-grained Gneiss

is Granitic gneiss

Calc-silicate rock

$\square \quad$ Impure marble

Fig. 3 Harker variation diagrams plotting $\mathrm{SiO}_{2}$ versus some selective major and minor oxides of whole-rock analyses.

the pattern of paragneiss from the Çine submassif of the Menderes Massif, Western Anatolia [20]; they are quite different from the pattern of orthogneiss from Wenquan metamorphic core complex in NW Chinese Tianshan [21]. REE elements may indicate sedimentary provenance. Most of coarse-grained gneiss and fine-grained gneiss have similar patterns with elevated LREE and relatively flat HREE with some negative Eu anomalies. Eu anomalies should be affected by feldspar content in these rocks.

\section{Metamorphism}

The Lan Sang metamorphic suites located in western Thailand are a part of Chiang Mai-Lincang Belt (CM-LB), and it is associated with plutonic intru- sion $[2,7,10]$. Based on field investigation and petrographic study, these metamorphic suites are mostly represented by gneissic rock, calc-silicate rocks and granitic gneiss under high-grade metamorphism condition. Two stages of metamorphism are observed. The first stage has been metamorphosed under the high-grade equilibrium condition represented by main granoblastic quartz, feldspar, and pyroxene with lepidoblastic biotite in most of gneisses. Therefore, metamorphic reactions are clearly involved by these assemblages, as also shown in pseudosection (Fig. 5a). In calc-silicate rocks, metamorphic reactions may be essentially involved by calcite, quartz, pyroxene, and garnet. The other stages are observed in gneisses, which may have 


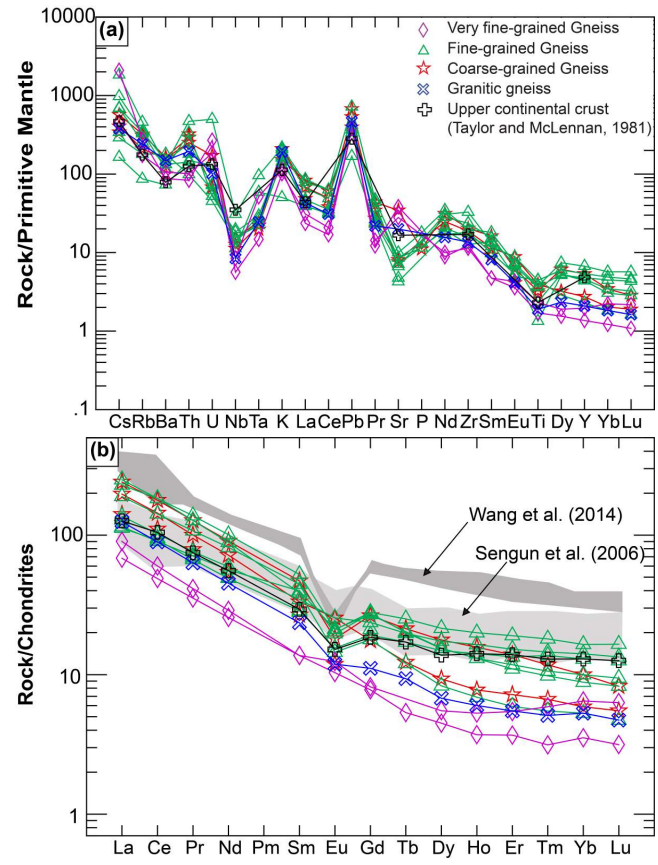

Fig. 4 Plots of trace and rare earth elements obtained from gneiss samples in the Lan Sang National Park that are comparable to the average upper continental crust. (a) Primitive mantle-normalized spider diagrams [11], (b) Chondrite-normalized REE patterns [11] of gneiss samples are compared to light grey shade pattern of paragneiss reported by Sengun et al [20], dark grey shade pattern of orthogneiss reported by Wang et al [21].

been retrograde metamorphism represented by reaction rim between biotite and chlorite, particularly in gneisses, likely indicating greenschist facies.

On the other hand, the main mineral assemblages significantly correspond to amphibolite facies. P-T estimation yields $570-590^{\circ} \mathrm{C}$ and 5.8-8.1 Kbar (Fig. 5a). These results are close to previous researches of paragneiss from Doi Intanon Core Complex $[3,4]$. They also suggested that a range of temperatures is between 535 and $725^{\circ} \mathrm{C}$, and pressure ranges from 3 to $7 \mathrm{Kbar}$. Another previous research of Nantasin [22] also indicated that rocks of Thabsila metamorphic complex undertaken medium amphibolite facies about $640-710^{\circ} \mathrm{C}$ and 5.5-8.0 Kbar. Both referred metamorphic complexes are located in the north and south of the study area, respectively, which they all belong to the CM-LB.

\section{Ancient tectonic setting}

According to the depositional tectonic discrimination diagram, using $\mathrm{Y}$ against $\mathrm{Nb}$ after Pearce [23],
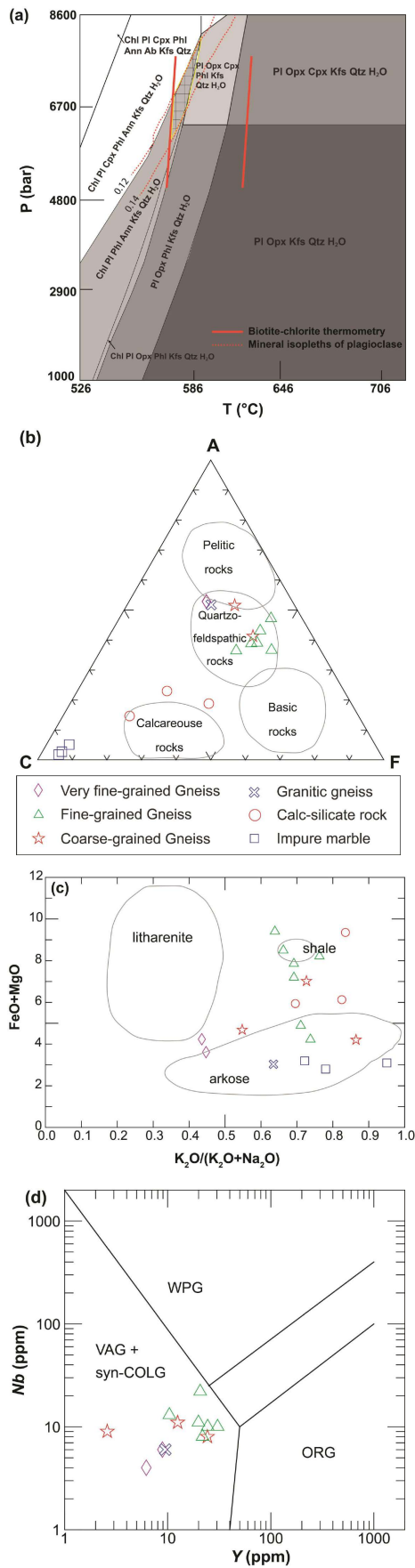

Fig. 5 (a) Pseudosection showing a coarse-grained gneiss (LS-23A) occurred at PT of $570-590^{\circ} \mathrm{C}$ and 5.8-8.1 Kbar. (b) ACF diagram [17] shows whole-rock compositions of all rock types, their potentially original rocks. (c) Diagram of $\mathrm{FeO}+\mathrm{MgO}$ versus $\mathrm{K}_{2} \mathrm{O} /\left(\mathrm{K}_{2} \mathrm{O}+\mathrm{Na}_{2} \mathrm{O}\right)[18,19]$ showing most of rock types potentially relate to arkose and shale compositions. (d) Plots of Y vs. Nb [23] showing these rocks are related to the volcanic arc and syn-collisional granites. $\mathrm{WPG}=$ within plate granites, $\mathrm{VAG}=$ volcanic arc granites, $\mathrm{COLG}=$ collision granites, $\mathrm{ORG}=$ ocean ridge granites. 
(a) Late Triassic - Early Jurassic

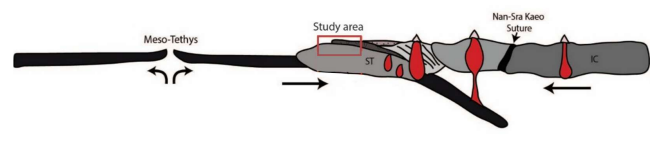

(b) Late Cretaceous - Paleocene

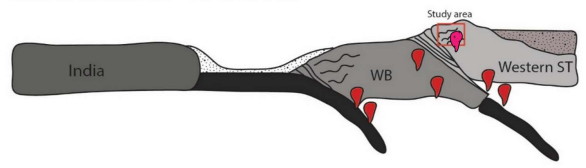

(c) Eocene

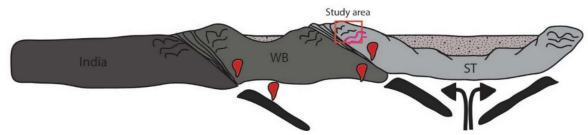

Fig. 6 Tectonic evolution model of the study area (revised after $[25,28])$. (a) Original sedimentary rocks after collisions of Shan Thai (ST), Nakhon-Thai, LampangChiang Rai, and Indochina (IC) in Late Triassic-Early Jurassic. (b) Metamorphism had occurred prior to the collision between Indian plate and Western Burma (WB) plate then led to partial melting of granitic composition in this area. (c) Indian-Eurasian collision induced the next metamorphism and ductile-brittle stage indicated by foliation along the sinistral strike-slip Mae Ping Fault during Eocene period.

all the original rocks would have occurred within an active continental margin (Fig. 5d). The main tectonic event in the study area, Lan Sang National Park, may have started from the collision between Western Burma block and Shan Thai (Fig. 6a) during Late Triassic-Early Jurassic ages [3]; Western Burma block was rifted from Gondwana in Late Triassic $[24,25]$. Consequently, the original rocks with quartzo-feldspathic compositions situated in the Shan Thai block had been metamorphosed (Fig. 6b).

In Late Cretaceous to Paleocene, the thermal overprinting event from regional metamorphism has been observed in granite-migmatite gneiss complex in Thailand along Northward to Southward core complex (Fig. 6b). Radiometric dating studies (ages 60-80 Ma) was investigated and interpreted as partial melting of granitic dike cross-cutting into the host rock also observable in the study area (Fig. 6b) $[7,26]$. Based on the U-Pb dating of monazite, it indicates that upper amphibolite facies involving granite-migmatite gneiss with partial melting may take place at the same time in Late
Cretaceous [3] . Subsequently, the ductile stage was evidenced by Mae Ping strike-slip fault (MPF) at 37-45 $\mathrm{Ma}$ [7] after India and Eurasia collision in Early Eocene (50-55 Ma, [27]) (Fig. 6c). There are indicators of the lower limit of the maximum age of left-lateral shear fabrics [6] and initiation of MPF prior to the transgressional uplifting of mylonite zone at about 23.5 Ma [2].

\section{CONCLUSION}

Lan Sang Metamorphic Suites can be divided into three main groups, including gneisses with various grain sizes from coarse-grained gneiss to very fine-grained gneiss, calc-silicate rock, and granitic gneiss. Analytical data indicate that quartzofeldspathic rocks appear to be the original rocks of gneissic rocks. These rocks represent paragneiss, which have undertaken lower amphibolite facies with P-T range between $570-590^{\circ} \mathrm{C}$ and $5.8-$ 8.1 Kbar. Calc-silicate rock and impure marble usually show strong deformation which should be inherited from the original calcareous sedimentary rocks.

Three stages of tectonic evolution are reconstructed. Original sedimentary rocks were subsequently formed after the collision between Shan Thai and Western Burma in Late Triassic-Early Jurassic. Subsequently, metamorphism appears to have taken place prior to the collision between Indian plate and Western Burma plate. Finally, the collision between Indian plate and Eurasian plate may reach to the peak of metamorphism and ductile-brittle stage of these rocks along the sinistral strike-slip MPF during Eocene period.

\section{Appendix A. Supplementary data}

Supplementary data associated with this article can be found at http://dx.doi.org/10.2306/ scienceasia1513-1874.2020.066.

Acknowledgements: The first author was supported by the 90th Anniversary of Chulalongkorn University Fund Ratchadaphiseksomphot Endowment Fund, Graduate School, Chulalongkorn University. The authors are also grateful to Dr. Alongkot Funka for his assistance during sample collections.

\section{REFERENCES}

1. Bunopas S, Vella P (1992) Geotectonics and geologic evolution of Thailand. In: Proceeding of the National Conference on Geologic Resources of Thailand: Potential for future Development, Bangkok, Thailand.

2. Lacassin R, Maluski H, Leloup PH, Tapponnier P, Hinthong C, Siribhakdi K, Chuaviroj S, Charoenravat 
A (1997) Tertiary diachronic extrusion and deformation of western Indochina: structural and ${ }^{40} \mathrm{Ar} /{ }^{39} \mathrm{Ar}$ evidence from NW Thailand. $J$ Geophys Res Solid Earth 102, 10013-10037.

3. Macdonald AS, Barr SM, Dunning GR, Yaowanoiyothin W (1993) The Doi Inthanon metamorphic core complex in NW Thailand: age and tectonic significance. $J$ Southeast Asian Earth Sci 8, 117-125.

4. Macdonald AS, Barr SM, Miller BV, Reynolds PH, Rhodes BP, Yokart B (2010) P-T-t constraints on the development of the Doi Inthanon metamorphic core complex domain and implications for the evolution of the western gneiss belt, northern Thailand. J Asian Earth Sci 37, 82-104.

5. Salayapongse S (2002) Metamorphic rocks of Thailand. In: Proceedings of the Symposium on Mineral, Energy, and Water Resources of Thailand: Towards the Year 2000, Bangkok, Thailand, 115-127.

6. Phajuy B, Singtuen V (2019) Petrochemical characteristics of Tak volcanic rocks, Thailand: Implication for tectonic significance. Sci Asia 45, 350-360.

7. Palin RM, Searle MP, Morley CK, Charusiri P, Horstwood MSA, Roberts NMW (2013) Timing of metamorphism of the Lan Sang gneiss and implications for left-lateral motion along the Mae Ping (Wang Chao) strike-slip fault, Thailand. J Asian Earth Sci 76, 120-136.

8. Ponmanee P, Kanjanapayont P, Grasemann B, KlÖtzli U, Choowong M (2016) Quantitative finite strain analysis of high-grade metamorphic rocks within the Mae Ping shear zone, western Thailand. Austrian $J$ Earth Sci 109, 233-240.

9. Department of Mineral Resources (2007) Geological Map of Changwat Tak. Department of Mineral Resources, Bangkok, Thailand.

10. Österle JE, KlÖtzli U, Stockli DF, Markus Khomenko P, Kanjanapayont P (2019) New age constraints on the Lan Sang gneiss complex, Thailand, and the timing of activity of the Mae Ping shear zone from in-situ and depth-profile zircon and monazite U-ThPb geochronology, J Asian Earth Sci 181, ID 103886.

11. Sun SS, McDonough WF (1989) Chemical and isotopic systematics of oceanic basalts: implications for mantle composition and processed. Geol Soc Spec Publ 42, 313-345.

12. Taylor SR, McLennan SM (1981) The composition and evolution of the continental crust: rare earth element evidence from sedimentary rocks. Phil Trans $R$ Soc Lon A 301, 381-399.

13. Connolly JAD (1995) Phase diagram methods for graphitic rocks and application to the system C-O$\mathrm{H}-\mathrm{FeO}-\mathrm{TiO}_{2}-\mathrm{SiO}_{2}$. Contrib Mineral Petr 119, 94-116.

14. Connolly JAD (2005) Computation of phase equilibria by linear programming: A tool for geodynamic modeling and its application to subduction zone decarbonation. Earth Planet Sc Lett 236, 524-541.
15. Holland TJB, Powell R (1990) An enlarged and updated internally consistent thermodynamic dataset with uncertainties and correlations: the system $\mathrm{K}_{2} \mathrm{O}$ $\mathrm{Na}_{2} \mathrm{O}-\mathrm{CaO}-\mathrm{MgO}-\mathrm{MnO}-\mathrm{FeO}-\mathrm{Fe}_{2} \mathrm{O}_{3}-\mathrm{Al}_{2} \mathrm{O}_{3}-\mathrm{TiO}_{2}-\mathrm{SiO}_{2}$ $\mathrm{C}-\mathrm{H}_{2}-\mathrm{O}_{2}$. J Metamorph Geol 8, 89-124.

16. Dachs E (2004) PET: petrological elementary tools for mathematica: an update. Comput Geosci-UK 30, 173-182.

17. Eskola P (1915) On the relation between chemical and mineralogical composition in the metamorphic rocks of the Orijarvi region. Bull Geol Soc Finl 44, 114-117.

18. Taylor SR, McLennan SM (1985) The Continental Crust, its Composition and Evolution: an Examination of the Geochemical Record Preserved in Sedimentary Rocks, Blackwell Scientific, Oxford, Boston.

19. Pettijohn FJ, Potter PE, Siever R (1987) Sand and Sandstone, 2nd edn, Springer, New York.

20. Sengun F, Candan O, Dora OÖ, Koralay OE (2006) Petrography and geochemistry of paragneisses in the Çine Submassif of the Menderes Massif, Western Anatolia. Turk $J$ Earth Sci 15, 321-342.

21. Wang B, Liua H, Shua L, Jahnb BM, Chungc SL, Zhaia Y, Liud D (2014) Early Neoproterozoic crustal evolution in northern Yili Block: insights from migmatite, orthogneiss and leucogranite of the Wenquan metamorphic complex in the NW Chinese Tianshan. Precambrian Res 242, 58-81.

22. Nantasin P, Hauzenbergera C, Liu X, Krenn K, Dong Y, ThÖni M, Wathanakul P (2012) Occurrence of the high grade Thabsila metamorphic complex within the low grade Three Pagodas shear zone, Kanchanaburi province, western Thailand: petrology and geochronology. J Asian Earth Sci 60, 68-87.

23. Pearce JA, Harris NBW, Tindle AG (1984) Trace element discrimination diagrams for the tectonic interpretation of granitic rocks. $J$ Petro 25, 956-983.

24. Metcalfe I (1996) Gondwanaland dispersion, Asian accretion and evolution of eastern tethys, Aust $J$ Earth Sci 43, 605-623.

25. Sone M, Metcalfe I (2008) Parallel Tethyan sutures in mainland Southeast Asia: new insights for PaleoTethys closure and implications for the Indosinian orogeny. CR Geosci 340, 166-179.

26. Ahrendt H, Hansen BT, Lumjuan A, Mickein A, Wemmer K (1997) Tectonometamorphic evolution of NW Thailand deduced from U/Pb-, Rb/Sr-, Sm/Nd- and $\mathrm{K} / \mathrm{Ar}$-isotope investigations. In: Proceeding of the International Conference on Stratigraphy and Tectonic Evolution of Southeast Asia and the South Pacific, Bangkok, Thailand, pp 314-319.

27. Hutchison CS (2007) Geological Evolution of South East Asia, 2nd edn, Kuala Lumpur, Geological Society of Malaysia.

28. Charusiri P, Daorerk V, Archibald D, Hisada K, Ampaiwan T (2002) Geotectonic evolution of Thailand: a new synthesis. J Geol Soc Thai 1, 1-20. 


\section{Appendix A. Supplementary data}

Table S1 Representative EPMA analyses of pyroxenes (in wt.\%) in various rock samples collected from the Lan Sang National Park.

\begin{tabular}{|c|c|c|c|c|c|c|c|c|c|c|c|}
\hline \multirow{2}{*}{ Name } & \multicolumn{4}{|c|}{ Fine-grained gneiss } & \multicolumn{4}{|c|}{ Calc-silicate } & \multicolumn{3}{|c|}{ Impure marble } \\
\hline & $\begin{array}{l}\text { LS1A- } \\
\text { px1 }\end{array}$ & $\begin{array}{l}\text { LS1A- } \\
\text { px3 }\end{array}$ & $\begin{array}{l}\text { LS1A- } \\
\text { px8 }\end{array}$ & $\begin{array}{l}\text { LS1A- } \\
\text { px11 }\end{array}$ & $\begin{array}{c}\text { LS14A- } \\
\text { px1 }\end{array}$ & $\begin{array}{c}\text { LS14A- } \\
\text { px2 }\end{array}$ & $\begin{array}{c}\text { LS14A- } \\
\text { px4 }\end{array}$ & $\begin{array}{c}\text { LS14A- } \\
\text { px7 }\end{array}$ & $\begin{array}{c}\text { LS12C- } \\
\text { px1 }\end{array}$ & $\begin{array}{c}\text { LS12C- } \\
\text { px3 }\end{array}$ & $\begin{array}{l}\text { LS12C- } \\
\text { px6 }\end{array}$ \\
\hline $\mathrm{SiO}_{2}$ & 56.79 & 54.54 & 57.35 & 55.04 & 55.14 & 56.56 & 55.85 & 56.70 & 57.08 & 54.96 & 55.78 \\
\hline $\mathrm{TiO}_{2}^{2}$ & 0.04 & 0.27 & 0.09 & 0.22 & 0.18 & 0.09 & 0.07 & 0.05 & 0.03 & 0.06 & 0.03 \\
\hline $\mathrm{Al}_{2} \mathrm{O}_{3}$ & 1.43 & 4.41 & 1.81 & 3.62 & 2.40 & 2.09 & 2.44 & 2.02 & 1.84 & 3.68 & 2.28 \\
\hline $\mathrm{FeO}$ & 7.35 & 6.83 & 7.21 & 6.48 & 14.32 & 10.78 & 11.94 & 10.36 & 5.05 & 8.83 & 9.58 \\
\hline $\mathrm{MnO}$ & 0.15 & 0.71 & 0.16 & 0.18 & 0.16 & 0.07 & 0.11 & 0.08 & 0.02 & 0.07 & 0.04 \\
\hline $\mathrm{MgO}$ & 19.48 & 18.95 & 19.55 & 19.21 & 14.33 & 17.17 & 15.46 & 16.92 & 20.69 & 17.68 & 17.88 \\
\hline $\mathrm{CaO}$ & 13.16 & 12.95 & 13.29 & 12.91 & 12.65 & 12.82 & 13.53 & 13.07 & 13.58 & 13.67 & 13.18 \\
\hline $\mathrm{Na}_{2} \mathrm{O}$ & 0.14 & 0.47 & 0.12 & 0.33 & 0.31 & 0.32 & 0.24 & 0.25 & 0.22 & 0.39 & 0.25 \\
\hline $\mathrm{K}_{2} \mathrm{O}$ & 0.07 & 0.35 & 0.08 & 0.28 & 0.15 & 0.16 & 0.08 & 0.11 & 0.13 & 0.18 & 0.17 \\
\hline Total & 98.60 & 99.48 & 99.67 & 98.27 & 99.64 & 100.06 & 99.72 & 99.56 & 98.64 & 99.52 & 99.19 \\
\hline $\mathrm{Si}$ & 2.098 & 1.988 & 2.096 & 2.029 & 2.082 & 2.089 & 2.088 & 2.089 & 2.085 & 2.021 & 2.066 \\
\hline $\mathrm{Ti}$ & 0.001 & 0.007 & 0.002 & 0.006 & 0.005 & 0.003 & 0.002 & 0.003 & 0.001 & 0.002 & 0.001 \\
\hline $\mathrm{Al}$ & 0.062 & 0.189 & 0.078 & 0.157 & 0.107 & 0.091 & 0.108 & 0.091 & 0.079 & 0.159 & 0.100 \\
\hline $\mathrm{Fe}^{3+}$ & 0.000 & 0.000 & 0.000 & 0.000 & 0.000 & 0.000 & 0.000 & 0.000 & 0.000 & 0.000 & 0.000 \\
\hline $\mathrm{Fe}^{2+}$ & 0.227 & 0.208 & 0.220 & 0.200 & 0.452 & 0.333 & 0.373 & 0.322 & 0.154 & 0.272 & 0.297 \\
\hline $\mathrm{Mn}$ & 0.005 & 0.022 & 0.005 & 0.006 & 0.005 & 0.002 & 0.003 & 0.003 & 0.001 & 0.002 & 0.001 \\
\hline $\mathrm{Mg}$ & 1.073 & 1.030 & 1.065 & 1.056 & 0.807 & 0.945 & 0.862 & 0.937 & 1.127 & 0.969 & 0.987 \\
\hline $\mathrm{Ca}$ & 0.521 & 0.506 & 0.520 & 0.510 & 0.512 & 0.507 & 0.542 & 0.520 & 0.532 & 0.539 & 0.523 \\
\hline $\mathrm{Na}$ & 0.010 & 0.033 & 0.009 & 0.024 & 0.023 & 0.023 & 0.017 & 0.018 & 0.016 & 0.028 & 0.018 \\
\hline K & 0.003 & 0.016 & 0.004 & 0.013 & 0.007 & 0.008 & 0.004 & 0.005 & 0.006 & 0.008 & 0.008 \\
\hline Total & 4.000 & 4.000 & 4.000 & 4.000 & 4.000 & 4.000 & 4.000 & 4.000 & 4.000 & 4.000 & 4.000 \\
\hline $\mathrm{Mg} /(\mathrm{Fe}+\mathrm{Mg})$ & 0.825 & 0.832 & 0.829 & 0.841 & 0.641 & 0.740 & 0.698 & 0.744 & 0.880 & 0.781 & 0.769 \\
\hline \multicolumn{12}{|l|}{ Atomic $\%$} \\
\hline $\mathrm{Ca}$ & 28.61 & 29.01 & 28.82 & 28.88 & 28.90 & 28.41 & 30.50 & 29.24 & 29.32 & 30.27 & 28.94 \\
\hline $\mathrm{Mg}$ & 58.92 & 59.05 & 58.98 & 59.80 & 45.56 & 52.94 & 48.49 & 52.67 & 62.16 & 54.47 & 54.63 \\
\hline $\mathrm{Fe}$ & 12.47 & 11.94 & 12.20 & 11.32 & 25.54 & 18.65 & 21.01 & 18.09 & 8.51 & 15.26 & 16.42 \\
\hline
\end{tabular}


Table S2 Representative EPMA analyses of plagioclases (in wt.\%) in various rock samples collected from the Lan Sang National Park.

\begin{tabular}{|c|c|c|c|c|c|c|c|c|c|c|c|}
\hline \multirow{2}{*}{ Name } & \multicolumn{2}{|c|}{$\begin{array}{l}\text { Coarse-grained } \\
\text { gneiss }\end{array}$} & \multicolumn{2}{|c|}{$\begin{array}{l}\text { Fine-grained } \\
\text { gneiss }\end{array}$} & \multicolumn{2}{|c|}{$\begin{array}{l}\text { Very fine- } \\
\text { grained gneiss }\end{array}$} & \multicolumn{2}{|c|}{$\begin{array}{l}\text { Granitic } \\
\text { gneiss }\end{array}$} & \multirow{2}{*}{$\begin{array}{c}\begin{array}{c}\text { Calc- } \\
\text { silicate }\end{array} \\
\text { LS14A- } \\
\text { plg2 }\end{array}$} & \multicolumn{2}{|c|}{$\begin{array}{l}\text { Impure } \\
\text { marble }\end{array}$} \\
\hline & $\begin{array}{c}\text { LS23C- } \\
\text { plg1 }\end{array}$ & $\begin{array}{c}\text { LS23C- } \\
\text { plg2 }\end{array}$ & $\begin{array}{l}\text { LS1A- } \\
\text { plg1 }\end{array}$ & $\begin{array}{l}\text { LS1A- } \\
\text { plg2 }\end{array}$ & $\begin{array}{l}\text { LS12A- } \\
\text { plg2c }\end{array}$ & $\begin{array}{l}\text { LS12A- } \\
\text { plg3r }\end{array}$ & $\begin{array}{l}\text { LS5A- } \\
\text { plg3 }\end{array}$ & $\begin{array}{l}\text { LS5A- } \\
\text { plg4 }\end{array}$ & & $\begin{array}{l}\text { LS12C- } \\
\text { plg1 }\end{array}$ & $\begin{array}{l}\text { LS12C- } \\
\text { plg7 }\end{array}$ \\
\hline $\mathrm{SiO}_{2}$ & 61.78 & 60.16 & 60.47 & 60.22 & 60.60 & 61.01 & 60.56 & 60.29 & 58.54 & 59.38 & 57.24 \\
\hline $\mathrm{TiO}_{2}$ & 0.01 & 0.03 & 0.00 & 0.00 & 0.00 & 0.00 & 0.01 & 0.02 & 0.02 & 0.00 & 0.00 \\
\hline $\mathrm{Al}_{2} \mathrm{O}_{3}$ & 22.83 & 22.93 & 24.08 & 25.32 & 25.27 & 25.43 & 22.57 & 23.47 & 21.95 & 24.70 & 25.80 \\
\hline $\mathrm{FeO}$ & 0.31 & 0.13 & 0.03 & 0.08 & 0.06 & 0.04 & 0.06 & 0.05 & 0.22 & 0.07 & 0.15 \\
\hline $\mathrm{MnO}$ & 0.01 & 0.00 & 0.00 & 0.00 & 0.00 & 0.02 & 0.00 & 0.04 & 0.00 & 0.03 & 0.02 \\
\hline $\mathrm{MgO}$ & 0.00 & 0.00 & 0.00 & 0.00 & 0.01 & 0.00 & 0.00 & 0.00 & 0.13 & 0.00 & 0.00 \\
\hline $\mathrm{CaO}$ & 8.77 & 8.21 & 6.97 & 6.99 & 7.98 & 8.06 & 8.02 & 8.11 & 8.77 & 8.19 & 7.37 \\
\hline $\mathrm{Na}_{2} \mathrm{O}$ & 3.46 & 4.05 & 7.76 & 7.49 & 4.10 & 4.13 & 4.17 & 4.07 & 3.45 & 3.84 & 4.95 \\
\hline $\mathrm{K} 2 \mathrm{O}$ & 0.13 & 0.16 & 0.07 & 0.08 & 0.13 & 0.13 & 0.26 & 0.23 & 0.20 & 0.14 & 0.15 \\
\hline Total & 97.30 & 95.67 & 99.38 & 100.18 & 98.15 & 98.82 & 95.65 & 96.28 & 93.28 & 96.35 & 95.68 \\
\hline $\mathrm{Si}$ & 2.794 & 2.770 & 2.710 & 2.677 & 2.717 & 2.717 & 2.788 & 2.759 & 2.771 & 2.715 & 2.648 \\
\hline $\mathrm{Ti}$ & 0.000 & 0.001 & 0.000 & 0.000 & 0.000 & 0.000 & 0.000 & 0.001 & 0.001 & 0.000 & 0.000 \\
\hline $\mathrm{Al}$ & 1.217 & 1.245 & 1.272 & 1.326 & 1.335 & 1.335 & 1.225 & 1.265 & 1.224 & 1.331 & 1.407 \\
\hline $\mathrm{Fe}$ & 0.012 & 0.005 & 0.001 & 0.003 & 0.002 & 0.002 & 0.002 & 0.002 & 0.009 & 0.002 & 0.006 \\
\hline $\mathrm{Mn}$ & 0.000 & 0.000 & 0.000 & 0.000 & 0.000 & 0.001 & 0.000 & 0.001 & 0.000 & 0.001 & 0.001 \\
\hline $\mathrm{Mg}$ & 0.000 & 0.000 & 0.000 & 0.000 & 0.001 & 0.000 & 0.000 & 0.000 & 0.009 & 0.000 & 0.000 \\
\hline $\mathrm{Ca}$ & 0.420 & 0.400 & 0.331 & 0.329 & 0.378 & 0.380 & 0.391 & 0.392 & 0.439 & 0.396 & 0.360 \\
\hline $\mathrm{Na}$ & 0.303 & 0.361 & 0.674 & 0.646 & 0.356 & 0.357 & 0.372 & 0.361 & 0.317 & 0.340 & 0.444 \\
\hline K & 0.008 & 0.009 & 0.004 & 0.004 & 0.008 & 0.007 & 0.015 & 0.013 & 0.012 & 0.008 & 0.009 \\
\hline Total & 4.753 & 4.792 & 4.993 & 4.985 & 4.797 & 4.798 & 4.793 & 4.795 & 4.781 & 4.794 & 4.875 \\
\hline \multicolumn{12}{|c|}{ Atomic \% } \\
\hline An & 57.40 & 51.90 & 32.80 & 33.50 & 51.00 & 51.00 & 50.20 & 51.20 & 57.20 & 53.20 & 44.30 \\
\hline $\mathrm{Ab}$ & 41.50 & 46.90 & 66.80 & 66.00 & 48.00 & 48.00 & 47.90 & 47.10 & 41.20 & 45.70 & 54.60 \\
\hline Or & 1.10 & 1.20 & 0.40 & 0.50 & 1.00 & 1.00 & 1.90 & 1.70 & 1.60 & 1.10 & 1.10 \\
\hline
\end{tabular}


Table S3 Representative EPMA analyses of K-feldspars (in wt.\%) in various rock samples collected from the Lan Sang National Park.

\begin{tabular}{|c|c|c|c|c|c|c|c|c|c|c|}
\hline \multirow{2}{*}{ Name } & \multicolumn{2}{|c|}{$\begin{array}{l}\text { Coarse-grained } \\
\text { gneiss }\end{array}$} & \multicolumn{2}{|c|}{$\begin{array}{l}\text { Fine-grained } \\
\text { gneiss }\end{array}$} & \multicolumn{2}{|c|}{$\begin{array}{l}\text { Very fine-grained } \\
\text { gneiss }\end{array}$} & \multicolumn{2}{|c|}{$\begin{array}{l}\text { Granitic } \\
\text { gneiss }\end{array}$} & \multicolumn{2}{|c|}{$\begin{array}{l}\text { Impure } \\
\text { marble }\end{array}$} \\
\hline & $\begin{array}{l}\text { LS23C- } \\
\text { kfs1 }\end{array}$ & $\begin{array}{l}\text { LS23C- } \\
\text { kfs2 }\end{array}$ & $\begin{array}{l}\text { LS1A- } \\
\text { kfs1 }\end{array}$ & $\begin{array}{l}\text { LS1A- } \\
\text { kfs2 }\end{array}$ & $\begin{array}{l}\text { LS12A- } \\
\text { kfs2 }\end{array}$ & $\begin{array}{l}\text { LS12A- } \\
\text { kfs3 }\end{array}$ & $\begin{array}{l}\text { LS5A- } \\
\text { kfs3 }\end{array}$ & $\begin{array}{l}\text { LS5A- } \\
\text { kfs4 }\end{array}$ & $\begin{array}{l}\text { LS12C- } \\
\text { kfs1 }\end{array}$ & $\begin{array}{l}\text { LS12C- } \\
\text { kfs } 2\end{array}$ \\
\hline $\mathrm{SiO}_{2}$ & 64.72 & 64.70 & 64.28 & 64.99 & 68.67 & 63.47 & 63.73 & 63.59 & 63.23 & 62.67 \\
\hline $\mathrm{TiO}_{2}$ & 0.00 & 0.04 & 0.03 & 0.01 & 0.00 & 0.01 & 0.00 & 0.01 & 0.01 & 0.00 \\
\hline $\mathrm{Al}_{2} \mathrm{O}_{3}$ & 18.17 & 18.01 & 17.97 & 18.24 & 17.80 & 18.91 & 17.04 & 17.17 & 18.67 & 18.70 \\
\hline $\mathrm{FeO}$ & 0.04 & 0.03 & 0.00 & 0.10 & 0.11 & 0.14 & 0.08 & 0.16 & 0.04 & 0.00 \\
\hline $\mathrm{MnO}$ & 0.00 & 0.00 & 0.00 & 0.00 & 0.00 & 0.00 & 0.00 & 0.01 & 0.00 & 0.01 \\
\hline $\mathrm{MgO}$ & 0.02 & 0.01 & 0.00 & 0.00 & 0.00 & 0.03 & 0.00 & 0.00 & 0.01 & 0.00 \\
\hline $\mathrm{CaO}$ & 0.05 & 0.05 & 0.02 & 0.02 & 0.45 & 0.02 & 0.00 & 0.00 & 0.00 & 0.03 \\
\hline $\mathrm{Na}_{2} \mathrm{O}$ & 0.75 & 1.14 & 0.51 & 0.66 & 1.45 & 0.49 & 0.63 & 0.46 & 0.81 & 0.72 \\
\hline $\mathrm{K}_{2} \mathrm{O}$ & 15.40 & 15.09 & 15.68 & 15.51 & 12.34 & 15.87 & 15.57 & 16.06 & 15.56 & 15.81 \\
\hline Total & 99.14 & 99.07 & 98.49 & 99.54 & 100.82 & 98.93 & 97.05 & 97.45 & 98.33 & 97.94 \\
\hline $\mathrm{Si}$ & 3.006 & 3.007 & 3.009 & 3.007 & 3.075 & 2.967 & 3.031 & 3.021 & 2.971 & 2.963 \\
\hline $\mathrm{Ti}$ & 0.000 & 0.001 & 0.001 & 0.000 & 0.000 & 0.000 & 0.000 & 0.000 & 0.000 & 0.000 \\
\hline $\mathrm{Al}$ & 0.995 & 0.987 & 0.991 & 0.995 & 0.939 & 1.042 & 0.955 & 0.961 & 1.034 & 1.042 \\
\hline $\mathrm{Fe}$ & 0.002 & 0.001 & 0.000 & 0.004 & 0.004 & 0.006 & 0.003 & 0.006 & 0.002 & 0.000 \\
\hline Mn & 0.000 & 0.000 & 0.000 & 0.000 & 0.000 & 0.000 & 0.000 & 0.000 & 0.000 & 0.000 \\
\hline $\mathrm{Mg}$ & 0.002 & 0.000 & 0.000 & 0.000 & 0.000 & 0.002 & 0.000 & 0.000 & 0.000 & 0.000 \\
\hline $\mathrm{Ca}$ & 0.002 & 0.003 & 0.001 & 0.001 & 0.021 & 0.001 & 0.000 & 0.000 & 0.000 & 0.002 \\
\hline $\mathrm{Na}$ & 0.068 & 0.102 & 0.047 & 0.059 & 0.126 & 0.044 & 0.058 & 0.042 & 0.074 & 0.066 \\
\hline $\mathrm{K}$ & 0.912 & 0.895 & 0.936 & 0.915 & 0.705 & 0.946 & 0.944 & 0.973 & 0.933 & 0.953 \\
\hline Total & 4.986 & 4.996 & 4.985 & 4.982 & 4.870 & 5.007 & 4.992 & 5.005 & 5.014 & 5.026 \\
\hline \multicolumn{11}{|c|}{ Atomic \% } \\
\hline An & 0.20 & 0.30 & 0.10 & 0.10 & 2.50 & 1.00 & 0.00 & 0.00 & 0.00 & 0.20 \\
\hline $\mathrm{Ab}$ & 6.90 & 10.20 & 4.70 & 6.10 & 14.70 & 4.40 & 5.80 & 4.20 & 7.30 & 6.50 \\
\hline Or & 92.90 & 89.50 & 95.20 & 93.80 & 82.70 & 95.50 & 94.20 & 95.80 & 92.70 & 93.40 \\
\hline
\end{tabular}


Table S4 Representative EPMA analyses of biotite (in wt.\%) in various rock samples collected from the Lan Sang National Park.

\begin{tabular}{|c|c|c|c|c|c|c|c|c|c|c|}
\hline \multirow{2}{*}{ Name } & \multicolumn{5}{|c|}{$\begin{array}{l}\text { Coarse-grained } \\
\text { gneiss }\end{array}$} & \multicolumn{2}{|c|}{$\begin{array}{c}\text { Very fine-grained } \\
\text { gneiss }\end{array}$} & \multicolumn{3}{|c|}{$\begin{array}{l}\text { Granitic } \\
\text { gneiss }\end{array}$} \\
\hline & $\begin{array}{l}\text { LS23C- } \\
\text { Bi1r }\end{array}$ & $\begin{array}{l}\text { LS23C- } \\
\text { Bi1c }\end{array}$ & $\begin{array}{l}\text { LS23C- } \\
\text { Bi2 }\end{array}$ & $\begin{array}{l}\text { LS23C- } \\
\text { Bi3r }\end{array}$ & $\begin{array}{l}\text { LS23C- } \\
\text { Bi7c }\end{array}$ & $\begin{array}{l}\text { LS16- } \\
\text { Bi3 }\end{array}$ & $\begin{array}{l}\text { LS16- } \\
\text { Bi4 }\end{array}$ & $\begin{array}{l}\text { LS5A- } \\
\text { Bi2 }\end{array}$ & $\begin{array}{l}\text { LS5A- } \\
\text { Bi3 }\end{array}$ & $\begin{array}{l}\text { LS5A- } \\
\text { Bi4 }\end{array}$ \\
\hline $\mathrm{SiO}_{2}$ & 37.18 & 32.27 & 37.12 & 38.30 & 37.22 & 41.01 & 37.78 & 37.35 & 37.73 & 37.91 \\
\hline $\mathrm{TiO}_{2}$ & 3.40 & 1.40 & 1.40 & 1.44 & 3.51 & 1.11 & 1.87 & 4.09 & 3.61 & 2.90 \\
\hline $\mathrm{Al}_{2} \mathrm{O}_{3}$ & 17.68 & 19.54 & 19.13 & 19.40 & 18.19 & 17.46 & 16.64 & 15.97 & 16.00 & 15.93 \\
\hline $\mathrm{FeO}_{\mathrm{t}}$ & 21.72 & 27.35 & 22.22 & 21.13 & 22.07 & 16.47 & 20.49 & 22.12 & 21.60 & 20.94 \\
\hline $\mathrm{MnO}$ & 0.03 & 0.07 & 0.01 & 0.00 & 0.02 & 0.01 & 0.16 & 0.20 & 0.27 & 0.25 \\
\hline $\mathrm{MgO}$ & 7.71 & 8.56 & 7.93 & 8.73 & 7.37 & 8.75 & 9.46 & 8.17 & 8.45 & 8.83 \\
\hline $\mathrm{CaO}$ & 0.01 & 0.09 & 0.17 & 0.06 & 0.04 & 0.21 & 0.04 & 0.04 & 0.06 & 0.05 \\
\hline $\mathrm{Na}_{2} \mathrm{O}$ & 0.09 & 0.01 & 0.02 & 0.06 & 0.09 & 27.00 & 0.07 & 0.07 & 0.07 & 0.07 \\
\hline $\mathrm{K}_{2} \mathrm{O}$ & 9.74 & 3.17 & 7.18 & 9.15 & 9.73 & 8.38 & 9.73 & 9.66 & 9.62 & 9.67 \\
\hline Total & 97.56 & 92.45 & 95.17 & 98.27 & 98.24 & 93.66 & 96.22 & 97.67 & 97.42 & 96.55 \\
\hline $\mathrm{Si}$ & 2.787 & 2.554 & 2.810 & 2.814 & 2.773 & 3.065 & 2.857 & 2.810 & 2.836 & 2.866 \\
\hline $\mathrm{Ti}$ & 0.192 & 0.083 & 0.079 & 0.080 & 0.197 & 0.062 & 0.106 & 0.231 & 0.204 & 0.165 \\
\hline $\mathrm{Al}$ & 1.562 & 1.823 & 1.706 & 1.680 & 1.597 & 1.538 & 1.483 & 1.416 & 1.418 & 1.419 \\
\hline $\mathrm{Fe}^{3+}$ & 0.000 & 0.000 & 0.000 & 0.000 & 0.000 & 0.000 & 0.000 & 0.000 & 0.000 & 0.000 \\
\hline $\mathrm{Fe}^{2+}$ & 1.362 & 1.810 & 1.406 & 1.298 & 1.375 & 1.029 & 1.296 & 1.392 & 1.358 & 1.324 \\
\hline Mn & 0.002 & 0.005 & 0.000 & 0.000 & 0.001 & 0.001 & 0.010 & 0.013 & 0.017 & 0.016 \\
\hline $\mathrm{Mg}$ & 0.862 & 1.009 & 0.895 & 0.956 & 0.819 & 0.975 & 1.067 & 0.916 & 0.947 & 0.995 \\
\hline $\mathrm{Ca}$ & 0.001 & 0.007 & 0.013 & 0.005 & 0.003 & 0.017 & 0.003 & 0.003 & 0.005 & 0.004 \\
\hline $\mathrm{Na}$ & 0.013 & 0.002 & 0.004 & 0.009 & 0.012 & 0.039 & 0.010 & 0.011 & 0.011 & 0.010 \\
\hline $\mathrm{K}$ & 0.932 & 0.320 & 0.693 & 0.857 & 0.925 & 0.798 & 0.938 & 0.927 & 0.922 & 0.933 \\
\hline Total & 7.712 & 7.612 & 7.606 & 7.699 & 7.701 & 7.523 & 7.769 & 7.719 & 7.717 & 7.731 \\
\hline
\end{tabular}


Table S5 Representative EPMA analyses of chlorite (in wt.\%) in various rock samples collected from the Lan Sang National Park.

\begin{tabular}{|c|c|c|c|c|c|c|c|c|c|}
\hline \multirow{2}{*}{ Name } & \multicolumn{4}{|c|}{ Coarse-grained gneiss } & \multicolumn{2}{|c|}{ Very fine-grained gneiss } & \multicolumn{3}{|c|}{ Granitic gneiss } \\
\hline & $\begin{array}{c}\text { LS23C- } \\
\text { chl1 }\end{array}$ & $\begin{array}{c}\text { LS23C- } \\
\text { chl2 }\end{array}$ & $\begin{array}{c}\text { LS23C- } \\
\text { chl3 }\end{array}$ & $\begin{array}{c}\text { LS23C- } \\
\text { chl4 }\end{array}$ & $\begin{array}{c}\text { LS12A- } \\
\text { chl1 }\end{array}$ & $\begin{array}{c}\text { LS12A- } \\
\text { chl2 }\end{array}$ & $\begin{array}{l}\text { LS5A- } \\
\text { chl3 }\end{array}$ & $\begin{array}{l}\text { LS5A- } \\
\text { chl4 }\end{array}$ & $\begin{array}{l}\text { LS5A- } \\
\text { chl5 }\end{array}$ \\
\hline $\mathrm{SiO}_{2}$ & 25.91 & 26.01 & 27.03 & 26.76 & 28.30 & 28.44 & 36.74 & 30.72 & 27.64 \\
\hline $\mathrm{TiO}_{2}$ & 0.24 & 0.03 & 0.46 & 0.16 & 0.04 & 0.01 & 0.71 & 0.35 & 0.27 \\
\hline $\mathrm{Al}_{2} \mathrm{O}_{3}$ & 21.36 & 21.12 & 20.44 & 21.30 & 20.12 & 20.23 & 16.64 & 18.24 & 18.24 \\
\hline $\mathrm{FeO}$ & 31.29 & 30.16 & 28.63 & 30.80 & 27.18 & 27.22 & 18.35 & 22.26 & 25.70 \\
\hline $\mathrm{MnO}$ & 0.13 & 0.09 & 0.11 & 0.12 & 0.13 & 0.18 & 0.04 & 0.06 & 0.07 \\
\hline $\mathrm{MgO}$ & 9.99 & 10.71 & 11.17 & 11.51 & 13.48 & 13.89 & 8.94 & 10.70 & 11.38 \\
\hline $\mathrm{CaO}$ & 0.03 & 0.08 & 0.05 & 0.06 & 0.05 & 0.08 & 0.58 & 0.13 & 0.10 \\
\hline $\mathrm{Na}_{2} \mathrm{O}$ & 0.00 & 0.03 & 0.01 & 0.02 & 0.02 & 0.02 & 0.73 & 0.06 & 0.05 \\
\hline $\mathrm{K}_{2} \mathrm{O}$ & 0.02 & 0.27 & 0.66 & 0.12 & 0.02 & 0.01 & 5.90 & 3.75 & 1.73 \\
\hline Total & 88.97 & 88.77 & 88.57 & 90.85 & 89.34 & 90.09 & 88.62 & 86.25 & 85.18 \\
\hline $\mathrm{Si}$ & 2.765 & 2.773 & 2.866 & 2.784 & 2.929 & 2.912 & 3.734 & 3.273 & 3.030 \\
\hline $\mathrm{Ti}$ & 0.019 & 0.024 & 0.037 & 0.012 & 0.003 & 0.001 & 0.054 & 0.028 & 0.022 \\
\hline $\mathrm{Al}$ & 2.687 & 2.652 & 2.553 & 2.611 & 2.454 & 2.447 & 1.993 & 2.290 & 2.357 \\
\hline $\mathrm{Fe}^{3+}$ & 0.000 & 0.000 & 0.000 & 0.000 & 0.000 & 0.000 & 0.000 & 0.000 & 0.000 \\
\hline $\mathrm{Fe}^{2+}$ & 2.793 & 2.688 & 2.538 & 2.679 & 2.353 & 2.336 & 1.559 & 1.983 & 2.356 \\
\hline $\mathrm{Mn}$ & 0.012 & 0.008 & 0.010 & 0.011 & 0.011 & 0.016 & 0.003 & 0.006 & 0.007 \\
\hline $\mathrm{Mg}$ & 1.590 & 1.702 & 1.765 & 1.785 & 2.081 & 2.125 & 1.355 & 1.699 & 1.861 \\
\hline $\mathrm{Ca}$ & 0.004 & 0.008 & 0.005 & 0.007 & 0.005 & 0.009 & 0.062 & 0.015 & 0.011 \\
\hline $\mathrm{Na}$ & 0.000 & 0.006 & 0.003 & 0.005 & 0.004 & 0.004 & 0.144 & 0.011 & 0.010 \\
\hline $\mathrm{K}$ & 0.002 & 0.037 & 0.089 & 0.016 & 0.003 & 0.001 & 0.765 & 0.510 & 0.242 \\
\hline Total & 9.873 & 9.899 & 9.866 & 9.909 & 9.844 & 9.859 & 9.670 & 9.815 & 9.896 \\
\hline
\end{tabular}


Table S6 Whole-rock analyses of rock samples from the Lan Sang National Park, Tak Province. Trace elements (ppm) obtained from ICP-MS analysis.

\begin{tabular}{|c|c|c|c|c|c|c|c|c|c|c|}
\hline \multirow[t]{2}{*}{ Name } & \multicolumn{2}{|c|}{$\begin{array}{l}\text { Coarse-grained } \\
\text { gneiss }\end{array}$} & \multicolumn{5}{|c|}{$\begin{array}{l}\text { Fine-grained } \\
\text { gneiss }\end{array}$} & \multicolumn{2}{|c|}{$\begin{array}{l}\text { Very fine-grained } \\
\text { gneiss }\end{array}$} & \multirow{2}{*}{$\begin{array}{c}\begin{array}{c}\text { Granitic } \\
\text { gneiss }\end{array} \\
\text { LS-5A }\end{array}$} \\
\hline & LS-5B & LS-23A & LS-4A & LS-4B & LS-10A & LS-10B & LS-12B & LS-12A & LS-16A & \\
\hline $\mathrm{Ba}$ & 1150 & 1110 & 1030 & 810 & 930 & 1260 & 930 & 740 & 610 & 1040 \\
\hline Co & 40 & 35 & 33 & 59 & 36 & 37 & 42 & 26 & 50 & 52 \\
\hline $\mathrm{Cr}$ & 70 & 40 & 70 & 90 & 50 & 60 & 80 & n.d. & 20 & 20 \\
\hline Cs & 5 & 3 & 8 & 6 & 5 & 2 & 15 & 4 & 17 & 3 \\
\hline $\mathrm{Ga}$ & 18 & 20 & 19 & 17 & 18 & 17 & 19 & 20 & 24 & 18 \\
\hline Gd & 4 & 5 & 6 & 4 & 6 & 5 & 6 & 2 & 2 & 2 \\
\hline $\mathrm{Hf}$ & 6 & 6 & 8 & 11 & 4 & 5 & 7 & 3 & 4 & 5 \\
\hline $\mathrm{Nb}$ & 11 & 8 & 11 & 13 & 10 & 10 & 22 & 4 & 6 & 6 \\
\hline $\mathrm{Ni}$ & 28 & 17 & 31 & 30 & 23 & 25 & 28 & 12 & 13 & 12 \\
\hline $\mathrm{Pb}$ & 38 & 28 & 30 & 26 & 30 & 28 & 51 & 27 & 27 & 33 \\
\hline $\mathrm{Rb}$ & 204 & 132 & 221 & 215 & 163 & 114 & 292 & 110 & 173 & 153 \\
\hline Sc & 9 & 6 & 10 & 10 & 13 & 14 & 7 & n.d. & n.d. & n.d. \\
\hline $\mathrm{Sr}$ & 170 & 730 & 180 & 140 & 150 & 180 & 210 & 590 & 810 & 420 \\
\hline Тa & 1 & 0.9 & 1 & 1.2 & 1 & 1 & 4 & 1 & 2 & 1 \\
\hline Th & 25 & 21 & 21 & 29 & 12 & 8 & 40 & 9 & 7 & 17 \\
\hline $\mathrm{U}$ & 1 & 4 & 2 & 1 & 1 & 1 & 11 & 4 & 6 & 2 \\
\hline V & 65 & 48 & 48 & 73 & 79 & 89 & 36 & 33 & 44 & 33 \\
\hline Y & 13 & 24 & 20 & 10 & 31 & 25 & 21 & 6 & 9 & 10 \\
\hline $\mathrm{Zn}$ & 48 & 45 & 63 & 57 & 39 & 60 & 41 & 46 & 48 & 34 \\
\hline $\mathrm{Zr}$ & 210 & 227 & 264 & 368 & 142 & 177 & 222 & 127 & 138 & 152 \\
\hline $\mathrm{La}$ & 47 & 57 & 45 & 59 & 27 & 32 & 54 & 21 & 16 & 30 \\
\hline $\mathrm{Ce}$ & 88 & 109 & 87 & 112 & 55 & 63 & 112 & 37 & 30 & 55 \\
\hline $\operatorname{Pr}$ & 10 & 12 & 10 & 12 & 7 & 7 & 13 & 4 & 3 & 6 \\
\hline $\mathrm{Nd}$ & 34 & 42 & 38 & 42 & 26 & 28 & 47 & 14 & 12 & 21 \\
\hline $\mathrm{Sm}$ & 5.1 & 7.2 & 6.8 & 5.9 & 6.1 & 5.3 & 8.0 & 2.1 & 2.1 & 3.6 \\
\hline $\mathrm{Eu}$ & 1.5 & 1.1 & 1.1 & 0.8 & 1.2 & 1.5 & 1.2 & 0.6 & 0.7 & 0.7 \\
\hline Gd & 3.6 & 5.5 & 5.7 & 3.7 & 5.8 & 4.9 & 5.6 & 1.6 & 1.7 & 2.3 \\
\hline $\mathrm{Tb}$ & 0.5 & 0.8 & 0.8 & 0.5 & 0.9 & 0.7 & 0.8 & 0.2 & 0.2 & 0.4 \\
\hline Dy & 2.4 & 4.5 & 3.9 & 2.1 & 5.5 & 4.4 & 3.9 & 1.1 & 1.4 & 1.7 \\
\hline Ho & 0.4 & 0.9 & 0.7 & 0.4 & 1.1 & 0.9 & 0.7 & 0.2 & 0.3 & 0.3 \\
\hline Er & 1.2 & 2.3 & 1.8 & 1.0 & 3.2 & 2.5 & 2.0 & 0.6 & 0.9 & 0.9 \\
\hline $\mathrm{Tm}$ & 0.2 & 0.3 & 0.3 & 0.1 & 0.5 & 0.4 & 0.3 & 0.1 & 0.2 & 0.1 \\
\hline $\mathrm{Yb}$ & 1.0 & 1.7 & 1.5 & 0.9 & 2.8 & 2.4 & 1.7 & 0.6 & 1.1 & 1.0 \\
\hline $\mathrm{Lu}$ & 0.1 & 0.2 & 0.2 & 0.1 & 0.4 & 0.3 & 0.2 & 0.1 & 0.2 & 0.1 \\
\hline
\end{tabular}

n.d. = not detected. 